\title{
PENGUATAN PENDIDIKAN KARAKTER PESERTA DIDIK MELALUI PROGRAM PENDIDIKAN BERNUANSA SURAU DAN BUDAYA MINANGKABAU
}

\author{
Heri Afridinata \\ Universitas Islam Negeri Imam Bonjol Padang \\ Email: heriafridinata@gmail.com \\ Duski Samad \\ Universitas Islam Negeri Imam Bonjol Padang \\ Email: duskisamad60@gmail.com \\ Muhammad Kosim \\ Universitas Islam Negeri Imam Bonjol Padang \\ Email: muhammadkosim@uinib.ac.id
}

\begin{abstract}
This study aims to describe and analyze the application of the character education program based surau and the Minangkabau culture strengthening program in intracurricular, extracurricular activities; and through school culture. This study used a qualitative approach and interviews, observation and documentation use to collect the data. Some teachers are respondents of the research. The results showed that the implementation of the Minangkabau culture and character education program in intracuricular activities were carried out by the subject teacher by incorporating the values of the Minangkabau nuanced character and culture into each learning. Character values were embedded in learning tools such as prayer and reading the Al-Qur'an before and after learning activities. Whereas the implementation of the character education program and the Minangkabau culture in extracurricular activities was carried out through the integration of the values of the character and the Minangkabau culture in various extracurricular activities such as muhadarah, An Nisa forum, Ar Rijal forum (studying Islamic sciences with the halaqah method), pesantren, and pray. While strengthening the values of Minangkabau cultural character can be seen in randai activities, traditional speeches, and Minangkabau cuisine. The results also showed that the development of school culture was carried out through strengthening the character of students such as Adiwiyata School, Healthy and Smoke-Free School Program. It is concluded that character education based surau and Minangkabau culture had helped educators more easily to develop students' character. The implication is that educators need to develop teaching materials that can help students improve their character.
\end{abstract}

Key Words: Strengthening program, education, surau, Minangkabau culture

\section{PENDAHULUAN}

Manusia merupakan makhluk beragama dan bertuhan (homo religius/homo divinous), artinya adalah makhluk yang memiliki fitrah untuk memahami dan menerima nilai-nilai kebenaran dan menjadikan kebenaran agama menjadi referensi (rujukan) dalam bersikap dan berperilaku sehari-hari. Selain itu, manusia adalah makhluk Allah Swt yang diberi sifat-sifat Rabbaniyah (sifat-sifat ketuhanan), sehingga manusia dijadikan oleh Allah Swt menjadi khalifah (pengelola) bumi beserta isinya. Pernyataan ini sesuai dengan firman Allah 
Swt dalam Al Qur'an, yaitu surah Al Baqarah ayat 30 sebagai berikut :

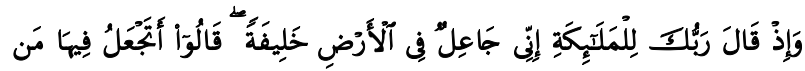

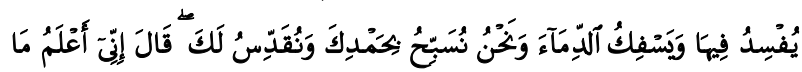
لَا تَعَلَمُونَ

“Ingatlah ketika Tuhanmu berfirman kepada para Malaikat: "Sesungguhnya aku hendak menjadikan seorang khalifah di muka bumi." Mereka berkata: "Mengapa Engkau hendak menjadikan (khalifah) di bumi itu orang yang akan membuat kerusakan padanya dan menumpahkan darah, padahal kami senantiasa bertasbih dengan memuji Engkau dan mensucikan Engkau?" Tuhan berfirman: "Sesungguhnya Aku mengetahui apa yang tidak kamu ketahui." (Qs. Al Baqarah: 30).

Salah satu fitrah manusia adalah manusia diberi oleh Allah Swt dua pilihan dalam hidup, yaitu pilihan takwa dan pilihan fujur/kufur, sesuai dengan penegasan Allah Swt dalam Qs. Asy Syams ayat 8-10 :

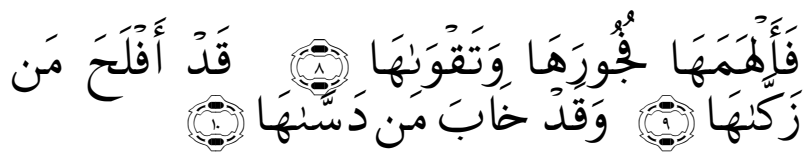

"Maka Allah mengilhamkan kepada jiwa itu (jalan) kefasikan dan ketakwaannya.Sesungguhnya beruntunglah orang yang mensucikan jiwa itu, Dan Sesungguhnya merugilah orang yang mengotorinya". (Qs. Asy Syams: 8-10)
Ayat diatas menjelaskan bahwa manusia dapat memilih antara jalur takwa dan jalur fujuraha,karena Allah Swt. menganugerahkan manusia banyak dimensi atau potensi diri, seperti:Pertama, Dimensi fisik (jasmani); organisme manusia merupakan organisme yang sempurna. Imam Al-Gazali menyebut dimensi fisik (jasmani) dengan namaruh jasmaniyah (ruh material); Kedua, Dimensi akal; merupakan pancaran dari Allah Swt sebagai fitrah Ilahi yang dapat memberikan ide-ide kreatif untuk mengembangkan dunia; Ketiga, Dimensi keberagamaan; manusia merupakan makhluk yang berketuhanan (homo divinous atau homo religious); Keempat, Dimensi ruhani (kejiwaan); dinamakan juga dimensi mental spiritual yang mampu memelihara dan menjamin ketentraman bathin; Kelima, Dimensi akhlak; seseorang yang memiliki sifat baik biasanya akan memiliki perangai atau akhlak yang baik juga dan sebaliknya seseorang yang memiliki perangai yang tidak baik cenderung memiliki akhlak yang tercela.

Berdasarkan beberapa dimensi fitrah manusia, maka peneliti ingin mengkaji dimensi/potensi kelima, yaitu akhlak, sebab pendidikan akhlak merupakan pendidikan awal yang dilaksanakan oleh Nabi Muhammad Saw.ketika beliau diangkat oleh Allah Swt. sebagai Rasulullah di kota Makkah.

Pendidikan akhlak juga disebut dengan pendidikan budi pekerti, tata krama, sopan santun, dan pendidikan moral. Satu dari bagian pendidikan akhlak adalah pendidikan karakter (character education atau character building). Undang-Undang Nomor 20 Tahun 2003 tentang Sistem Pendidikan Nasional Pasal 3 
menyebutkan bahwa, "Pendidikan nasional berfungsi mengembangkan kemampuan dan membentuk watak serta peradaban bangsa yang bermartabat dalam rangka mencerdaskan kehidupan bangsa, bertujuan untuk berkembangnya potensi peserta didik agar menjadi manusia yang beriman dan bertakwa kepada Tuhan Yang Maha Esa, berakhlak mulia, sehat, berilmu, cakap, kreatif, mandiri, dan menjadi warga negara yang demokratis serta bertanggung jawab".

Persoalan pendidikan akhlak atau pendidikan karakter dapat dipahami melalui isi pembelajaran (content of learning), kegiatan mendidik, mengajar, melatih dan membimbing.Bentuk program penguatan pendidikan karakter (PPK) yang selaras dengan Perpres RI Nomor 87 Tahun 2017 tentang penguatan pendidikan karakter adalah program penguatan pendidikan karakter peserta didik bernuansa surau dan budaya Minangkabau di SMK Negeri di wilayah Provinsi Sumatera Barat. Program ini sebenarnya telah berjalan sejak tahun 2013, sesuai dengan adanya Pergub Sumatera Barat Nomor 73 Tahun 2012 tentang Petunjuk Pelaksanaan Pendidikan Karakter di Sekolah/Madrasah.Program penguatan pendidikan karakter peserta didik bernuansa surau dan budaya Minangkabau di SMK Negeri Kabupaten Solok Selatan telah berjalan cukup baik. Pernyataan ini diperoleh melalui wawancara awal di SMKN 1 Solok Selatan dan SMKN 5 Solok Selatan. Efrizol, selaku kepala SMKN 1 Solok Selatan menjelaskan bahwa program penguatan pendidikan karakter peserta didik SMKN 1 Solok Selatan memadukan antara tiga dimensi nilai-nilai karakter yaitu nilai-nilai karakter nasional, surau dan budaya Minangkabau.SMKN 5 Solok Selatanjuga telah melaksanakan program penguatan pendidikan karakter bernuansa surau dan budaya Minangkabau melalui kegiatan ekstrakurikuler.Mulzamra, selaku Kepala SMKN 5 Solok Selatan menjelaskan bahwa kegiatan itu dilaksanakan berlandaskan nilai-nilai karakter nasional, surau dan budaya Minangkabau yang telah dilaksanakan mulai tahun 2016 (tahun ajaran 2016/2017).Masih menurut beliau, kegiatan penguatan pendidikan karakter peserta didik dilaksanakan melalui aspek intrakurikuler, ekstrakurikuler dan budaya sekolah. Berdasarkan paparan diatas, peneliti tertarik untuk mengangkat tema ini ke dalam penelitian lapangan (field research), dengan tujuan utama agar program penguatan pendidikan karakter bernuansa surau dan budaya Minangkabau yang telah terlaksana di SMKN 1 dan SMKN 5 Solok Selatan dapat dicontoh dan diterapkan di seluruh SMK Kabupaten Solok Selatan, baik negeri maupun swasta. Oleh karena itu, peneliti mengajukan judul penelitian, yaitu "Penguatan pendidikan karakter peserta didikmelalui program pendidikan karakter bernuansa surau dan budaya Minangkabau di SMK Negeri Kabupaten Solok Selatan".

Batasan masalah dalam tesis ini adalah sebagai berikut : (1) Penerapan program penguatan pendidikan karakter bernuansa surau dan budaya Minangkabau dalam kegiatan intrakurikuler (proses pembelajaran) di SMK Negeri Kabupaten Solok Selatan (SMKN 1 dan SMKN 5 Solok Selatan); (2) Penerapan program penguatan pendidikan karakter bernuansa surau dan budaya Minangkabau dalam kegiatan ekstrakurikuler di SMKNegeri Kabupaten Solok Selatan (SMKN 1 dan SMKN 5 Solok Selatan); dan (3) Penguatan pendidikan karakter peserta didik melaluibudaya 
sekolah di SMKN Negeri Kabupaten Solok Selatan (SMKN 1 dan SMKN 5 Solok Selatan).

Tujuan yang akan dicapai dalam penelitian adalah: (1) untuk mengetahui penerapan program penguatan pendidikan karakter bernuansa surau dan budaya Minangkabau dalam program intrakurikuler (pembelajaran) di SMK Negeri Kabupaten Solok Selatan (SMKN 1 dan SMKN 5 Solok Selatan); (2) untuk mengetahui penerapan program penguatan pendidikan karakter bernuansa surau dan budaya Minangkabau dalam program ekstrakurikuler di SMK Negeri Kabupaten Solok Selatan (SMKN 1 dan SMKN 1 Solok Selatan); dan (3) untuk mengetahui peran pengembangan budaya sekolah dalam memperkuat pendidikan karakter siswa di SMKN Negeri Kabupaten Solok Selatan (SMKN 1 dan SMKN 5 Solok Selatan).

Kegunaan penelitian ini adalah: (1) memenuhi salah satu syarat untuk menyelesaikan program Pascasarjana (S2) Pendidikan Agama Islam di Univesitas Islam Negeri (UIN) Imam Bonjol Padang Tahun 2019; (2) bahan masukan bagi satuan pendidikan dalam merancang program pendidikan karakter yang tepat bagi peserta didik SMKNegeri Kabupaten Solok Selatan; dan (3) bahan pertimbangan bagi satuan pendidikan dalam pemilihan metode penguatan pendidikan karakter peserta didikdi SMK Negeri Kabupaten Solok Selatan, terutama SMK Negeri yang belum menerapkan program pendidikan karakter bernuansa surau dan budaya Minangkabau.

Secara etimologi, karakter berasal dari bahasa Latin, "kharakter", "kharassein", "kharax", yang berarti membuat tajam dan membuat dalam. Sedangkan menurut pendapat Wynne sebagaimana yang dikutip oleh Mulyasa menerangkan bahwa "karakter" berasal dari bahasa Yunani yang berarti "to mark" (menandai) dan memfokuskan pada bagaimana menerapkan nilai-nilai kebaikan dalam tindakan nyata atau perilaku sehari-hari. Contohnya apabila seseorang berperilaku tidak jujur, curang, kejam, rakus dan tamak, maka orang tersebut akan disebut memiliki karakter jelek, sebaliknya apabila seseorang jujur, amanah, suka menolong, maka ia akan disebut berkarakter baik/mulia. Kamus Besar Bahasa Indonesia (KBBI) menjelaskan bahwa karakter adalah tabiat, watak, sifatsifat kejiwaan, akhlak atau budi pekerti yang membedakan antara seseorang dengan yang lain. Faktor pembeda tersebut meliputi kebiasaan, kesukaan, ketidaksukaan, kemampuan, kecendrungan, potensi diri, nilai-nilai dan pola pemikiran.

Kementerian Pendidikan Nasional Republik Indonesia mendefenisikan karakter sebagai nilai dasar perilaku yang menjadi acuan tata nilai interaksi antar manusia. Secara universal, karakter dirumuskan sebagai nilai hidup (way of values) berdasarkan pilar-pilar kedamaian (peace), menghargai (respect), kerja sama (cooperation), kebebasan (freedom), kebahagiaan (happiness), kejujuran (honesty), kerendahan hati (tawaddhu/ humality), kasih sayang (ar-Rahman/loving), tanggung jawab (responsibility), kesederhanaan (simplity), toleransi (tolerance) dan persatuan (unity).

Program pendidikan karakter pertama kali ditetapkan oleh Kementerian Pendidikan Nasional pada Hari Pendidikan Nasional (Hardiknas) tanggal 2 Mei 2011 yang lalu. Pendidikan karakter 
merupakan perwujudan amanat Pancasila dan Pembukaan Undang-Undang Dasar 1945 yang dilatarbelakangi oleh realita permasalahan kebangsaan, seperti banyaknya disintegrasi, belum dihayatinya nilai-nilai Pancasila, bergesernya nilai etika bangsa, dan melemahnya kemandirian bangsa.

Berdasarkan penelusuran terhadap beberapa literatur, defenisi pendidikan karakter adalah sebagai berikut: Pertama, Rencana Aksi Nasional Pendidikan Karakter menjelaskan bahwa pendidikan karakter disebut juga pendidikan nilai, pendidikan budi pekerti, pendidikan moral dan pendidikan watak yang bertujuan menanamkan kebiasaan (habituation) peserta didik, baik sisi kognitif, afektif, dan psikomotor; Kedua, Ratna Megawangi, pendidikan karakter merupakan usaha untuk mendidik anakanak agar dapat mengambil keputusan dengan bijak dan mempraktikkannya dalam kehidupan sehari-hari sehingga mereka dapat memberikan kontribusi positif pada lingkungannya; Ketiga, E. Mulyasa, pendidikan karakter adalah suatu sistem penanaman nilai-nilai karakter kepada peserta didik yang meliputi komponen kesadaran, pemahaman, kepedulian, dan komitmen yang tinggi untuk melaksanakan nilainilai tersebut, baik terhadap Tuhan YME, diri sendiri, sesama manusia, lingkungan, dan masyarakat serta bangsa secara keseluruhan, sehingga menjadi manusia yang sempurna sesuai kodratnya: Keempat, T. Ramli, pendidikan karakter adalah pendidikan yang esensinya sama dengan pendidikan akhlak yang bertujuan membentuk pribadi anak supaya menjadi manusia yang baik, warga masyaakat, dan warga Negara yang baik; Kelima, Menurut Buchori sebagaimana yang dikutip oleh
Masnur Muchlish menerangkan bahwa pendidikan karakter merupakan proses pendidikan yang membawa peserta didik ke pengenalan nilai secara kognitif, penghayatan nilai secara aktif dan akhirnya ke pengamalan nilai secara nyata.

Jadi, dapat disimpulkan bahwa pendidikan karakter adalah: Pertama, Proses pembelajaran yang memberdayakan guru dan peserta didik dalam komunitas sekolah untuk memahami, peduli, dan berbuat berlandaskan nilainilai etika/moral dan agama; Kedua, Proses pemberian nilai-nilai yang bertujuan mengembangkan kemampuan peserta didik untuk memberikan keputusan baik buruk, memelihara hal-hal yang baik, dan mewujudkan kebaikan dalam kehidupan sehari-hari dengan sepenuh hati; Ketiga, Suatu sistem penanaman nilai-nilai karakter kepada warga sekolah yang meliputi komponen pengetahuan, kesadaran atau kemauan sehingga peserta didik menjadi insan alkamil (manusia yang sempurna).

Penguatan pendidikan karakter dilaksanakan dengan cara menerapkan nilai-nilai Pancasila dalam pendidikan karakter terutama meliputi nilai-nilai religius, jujur, toleran, disiplin, bekerja keras, kreatif, mandiri, demokratis, rasa ingin tahu, semangat kebangsaan, cinta tanah air, menghargai prestasi, komunikatif, cinta damai, gemar membaca, peduli lingkungan, peduli sosial, dan bertanggung jawab.

Pendidikan di SMK tidak hanya proses pembentukan keterampilan teknis untuk pemenuhan kebutuhan ekonomi saja, akan tetapi tujuan pendidikan SMK (pendidikan vokasi) adalah pembentukan inkulturasi dan akulturasi, yaitu proses 
memperadabkan suatu generasi baru masa depan yang berlangsung di sekolah, keluarga, dunia industri, dunia usaha dan masyarakat. SMK memiliki ciri khas yang dapat membedakannya dengan SMA atau MA yaitu hubungan erat dengan dunia kerja, dunia usaha dan dunia industri, serta sistem pembelajarannya banyak menggunakan learning by doing. Penguatan pendidikan karakter di satuan pendidikan formal, seperti SMK Negeri dapat dilaksanakan secara terintegrasi dalam kegiatan intrakurikuler, ekstrakurikuler, dan pengembangan budaya/kultur sekolah.

Surau merupakan salah satu institusi pendidikan utama dalam kehidupan masyarakat Minangkabau dan merupakan ciri khas serta lambang keberadaan suatu suku. Pada awalnya surau dibangun untuk tempat beribadah dan kemudian menjadi tempat bermalam, surau mempunyai dua makna.Pertama, bermalam berarti tidur dan istirahat di malam hari. Kedua, bermalam berarti belajar dan menuntut ilmu pengetahuan. Belajar dalam konteks ini tidak dapat diartikan sebagai bentuk atau proses pendidikan seperti yang dilakukan sekarang. Belajar sebagai proses pendewasaan generasi muda yang repsentatif dan pemimpin yang bertanggung jawab.

Proses pendidikan yang berlangsung di surau sangat komprehensif sifatnya. Meskipun tidak terstruktur sebagaimana lazimnya institusi pendidikan formal, ternyata di surau terjadi proses pematangan diri dan sosialitas bagi para remaja dan anak-anak. Banyak tradisi kehidupan di surau "mengajarkan" tentang kemandirian, nilai-nilai kebersamaan, kegotongroyongan, bahkan juga kematangan berpikir, serta keterampilan dan kepiawaian dalam berargumen.Secara singkat, inti isi surau Minangkabau ada 3 (tiga), yaitu "mengaji", pendidikan budaya, dan pendidikan fisik (olah raga).Ketiga inti sari surau tersebut telah menggambarkan nilai-nilai karakter bangsa Indonesia.

Secara spesifik, karakteristik sistem pendidikan surau adalah sebagai berikut (a) Orang-orang yang belajar di surau disebut dengan "murid" dan gurunya dinamakan dengan "syaikh" atau "tuan guru" atau "guru tuo". Sehingga tumbuh karakter menghargai prestasi, artinya seorang murid akan sangat menghargai tuan gurunya; (b) pendidikan surau bertujuan membentuk karakter/pribadi yang sopan santun, berbudi baik (baso) yang indah, religius, dan memiliki kemampuan dalam menempuh kehidupan; (c) dalam perkembangan selanjutnya, murid yang belajar di surau disebut "urang siak","faqih" dan "faqir". Istilah urang siak muncul di wilayah Sumatera bagian timur yang sekarang merupakan wilayah Provinsi Riau.Istilah faqih menunjukkan orang yang mempunyai pengetahuan atau pemahaman atas sesuatu.Dan istilah faqir menunjukkan orang yang sangat membutuhkan, baik fisik maupun spiritual; dan (d) pengaturan pendidikan di surau lebih berdasarkan hubungan personal di kalangan penghuni surau itu sendiri, bukan berdasarkan formalitas birokrasi. Jadi, pendidikan surau merupakan suatu proses belajar untuk sosialisasi dan enkulturasi kultural daripada sekedar transfer ilmu pengetahuan.

Peraturan Gubernur Sumatera Barat Nomor 73 Tahun 2012 Bab I Pasal 4 menjelaskan bahwa ruang lingkup 
penguatan pendidikan karakter di sekolah/madrasah meliputi tiga macam, yaitu: (1) Nilai-nilai agama/Islam/ nuansa surau; (2) Nilai-nilai budaya bangsa/nasional/Indonesia; dan (3) Nilainilai budaya lokal/nuansa budaya Minangkabau (adat basandi syarak, syarak basandi kitabullah).Ketiga ruang lingkup penguatan pendidikan karakter di atas saling berkaitan dan berhubungan serta tidak dapat dipisahkan.Karena dalam sebuah kegiatan ekstrakurikuler di SMK pasti mengandung ketiga ruang lingkup tersebut. Contohnya kegiatan ekstrakurikuler randai.Kegiatan ini selain mengandung nilai-nilai karakter keMinangkabau-an, juga mengandung nilainilai karakter nasional dan ke-Islaman (surau).Strategi pelaksanaan penguatan pendidikan karakter benuansa surau dan budaya Minangkabau di SMK sesuai dengan Peraturan Gubernur Sumatera Barat Nomor 73 Tahun 2012, dilaksanakan melalui 3 (tiga) strategi, yaitu:Pertama, Kegiatan intrakurikuler sekolah; yaitu kegiatan mengintegrasikan nilai-nilai karakter Al Qur'an dan budaya Minangkabau ke dalam proses pembelajaran yang meliputi perencanaan (silabus dan RPP), pelaksanaan (proses pembelajaran) dan penilaian (evaluasi); Kedua, Kegiatan ekstrakurikuler sekolah, yaitu melaksanakan kegiatan ekstrakurikuler atau kegiatan tambahan di sekolah untuk memperkuat terwujudnya karakter bernuansa surau dan budaya Minangkabau di SMK. Kegiatan ini meliputi kegiatan ekstrakurikuler keagamaan Islam, kebangsaan, dan budaya lokal Minangkabau; Ketiga, Pengembangan budaya/kultur sekolah.

Budaya sekolah sebagai sekumpulan nilai yang melandasi perilaku, tradisi, kebiasaan keseharian, dan simbol-simbol yang dipraktikkan oleh kepala sekolah, guru, petugas administrasi, siswa, dan masyarakat sekitar sekolah. Budaya sekolah berkaitan erat pula dengan perilaku dan kebiasaan-kebiasaan warga sekolah. Substansi budaya sekolah adalah perilaku, nilai-nilai, sikap, dan cara hidup warga sekolah yang berusaha mendinamisir lingkungan sekolah untuk mencapai tujuan sekolah.

Budaya sekolah yang positif akan memberi warna sekolah. Budaya positif tersebut antara lain: budaya jujur, budaya saling percaya, budaya bersih, budaya disiplin, budaya baca, budaya kerjasama, budaya memberi teguran, budaya memberi penghargaan, dan lain-lain. Budaya tersebut tentunya ada di setiap satuan pendidikan, walaupun pelaksanaannya masih belum maksimal. Peranan budaya sekolah di SMK dalam penguatan pendidikan karakter akan berjalan dengan baik, jika melalui beberapa tahapan, yaitu sebagai berikut:

Tahap pertama: komitmen bersama antara warga sekolah tentang konsep pengembangan budaya sekolah. Misalnya: kesediaan menerima aturan kerja, kesepakatan target waktu, kesadaran melaksanakan tugas sesuai aturan (SOP), kesediaan bekerjasama, dan kesediaan melakukan sikap kerja sesuai dengan yang diharapkan dalam budaya sekolah yang sedang dibudayakan di lingkungan sekolah.

Tahap kedua adalah membangun. Kepala Sekolah sebagai seorang manajer dapat membangun budaya sekolah melalui "direct action" oleh seluruh warga sekolah. Misalnya: Setiap kegiatan pembelajaran disisipkan nilai-nilai budaya sekolah yang sedang dibudayakan di sekolah. 
Tahap ketiga adalah pemaknaan. Pada tahap ini nilai-nilai budaya sekolah telah berhasil dibudayakan oleh seluruh warga sekolah. Tahapan ini bertujuan untuk membangun apresiasi dari seluruh warga sekolah. Apresiasi ditunjukkan dengan indikator: memahami, menghayati, menyenangi, dan menghargai terhadap budaya sekolah yang sedang dibudayakan.

Tahap keempat adalah pembiasaan. Dalam tahap ini merupakan kegiatan yang dilaksanakan secara terus menerus. Menjadi suatu rutinitas dan menjadi karakter yang baik dalam perilaku berinteraksi oleh warga sekolah.

Tahap kelima adalah refleksi. Tahap inilah yang menjadikan nilai-nilai budaya sebagai bagian dari pola hidup yang memungkinkan seluruh warga sekolah dapat menyadari apa yang telah diperoleh dan dilakukan serta merenungkan apa yang telah dipelajarinya sebagai bagian dari proses belajar itu sendiri.

Budaya positif tersebut antara lain: budaya jujur, budaya saling percaya, budaya bersih, budaya disiplin, budaya baca, budaya kerjasama, budaya memberi teguran, budaya memberi penghargaan, dan lain-lain

\section{METODE PENELITIAN}

Metode yang digunakan dalam penelitian ini adalah metode kualitatif. Metode kualitatif adalah metode penelitian yan digunakan untuk meneliti pada kondisi objek yang alamiah, dimana peneliti sebagai instrumen kunci, teknik pengumpulan data dilakukan secara trianggulasi (gabungan), analisis data bersifat induktif, dan hasil penelitian kualitatif lebih menekankan makna.

Beberapa alasan peneliti dalam memilih metode kualitatif sebagai metode penelitian, yaitu: Pertama, Untuk memahami makna dibalik data yang tampak. Gejala sosial yang terjadi di lapangan tidak dapat dipahami hanya dengan memahami angka-angka, tetapi harus memahami makna dibalik data yang diperoleh. Maka dibutuhkan metode kualitatif dengan teknik observasi, wawancara, dan dokumentasi; Kedua, Untuk memahami interaksi sosial. Interaksi sosial yang kompleks hanya dapat diuraikan dengan metode kualitatif dengan teknik observasi, wawancara, dan dokumentasi; Ketiga, Untuk memahami perasaan orang. Perasaan orang sulit dipahami jika tidak diteliti dengan metode kualitatif dengan teknik wawancara mendalam dan observasi; Keempat, Untuk mengembangkan teori. Metode kualitatif paling cocok digunakan untuk mengembangkan teori yang dibangun melalui data yang diperoleh melalui lapangan.

Untuk memastikan kepastian data. Data sosial sering sulit dipastikan kebenarannya, maka digunakan metode penelitian kualitatif melalui teknik pengumpulan data secara trianggulasi (gabungan).

Jenis penelitian kualitatif yang digunakan adalah phenomenological research atau penelitian fenomenafenomena, yaitu salah satu jenis penelitian kualitatif, dimana dalam pengumpulan data (collecting data) dengan observasi untuk mengetahui fenomena esensial yang terjadi dilapangan.Tempat penelitian adalah lokasi yang digunakan dalam melakukan penelitian untuk 
memperoleh data yang diinginkan. Tempat penelitian tesis ini adalah sebagai berikut : (a) SMK Negeri 1 Solok Selatan, dengan alamat Jalan Raya Koto Baru - Muara Labuh KM. 3, Sungai Pagu, Pulakek Koto Baru, Kecamatan Sungai Pagu, Kabupaten Solok Selatan, Sumatera Barat 27776 dan (b) SMK Negeri 5 Solok Selatan, dengan alamat di Jalan Raya Pakan Rabaa Tangah, Kecamatan Koto Parik Gadang Diateh, Kabupaten Solok Selatan, Sumatera Barat. Sedangkan waktu penelitian adalah waktu berlangsungnya penelitian atau saat penelitian ini dilangsungkan. Penelitian dilakukan dilaksanakan dalam rentang waktu 2 (dua) bulan, yaitu tanggal 27 Juli s/d 27 September 2018. Dalam menentukan informan penelitian, peneliti menggunakan salah satu teknik sampling dalam penelitian, yaitu teknik sampling non probabiliti yang cenderung bersifat kualitatif. Yang dimaksud dengan teknik sampling non probabiliti adalah teknik pengambilan sampel penelitian yang tidak memberi peluang/kesempatan yang sama bagi setiap unsur atau anggota populasi untuk dipilih menjadi sampel. Teknik sampling yang digunakan dalam penelitian ini adalah teknik snowball sampling. Teknik snowball sampling adalah teknik penentuan sampel yang mula-mula jumlahnya kecil, kemudian membesar.Ibarat bola salju yang menggelinding yang lama-lama membesar. Snowball sampling merupakan metode sampling yang dilakukan melalui proses bergulir dari satu responden ke responden lainnya sehingga data-data yang dihasilkan semakin lama semakin dalam dan valid.Dalam penelitian ini, peneliti menggunakan 3 (tiga) macam teknik pengumpulan data, yaitu observasi, wawancara dan dokumentasi.Analisis data dalam penelitian kualitatif berbeda dengan penelitian kuantitatif. Analisis data penelitian kualitatif bersifat induktif (berpikir induktif dalam bidang ilmiah yang bertitik tolak dari sejumlah hal khusus untuk sampai pada suatu rumusan umum sebagai hukum ilmiah) dan berkelanjutan. Tujuan akhir analisis data kualitatif adalah memperoleh makna, menghasilkan pengertianpengertian, konsep-konsep dan mengembangkan teori-teori baru. Dalam penelitian ini, peneliti menggunakan teknik analisis data kualitatif versi Miles and Huberman, yang dikembangkan tahun 1984, yang meliputi reduksi data (data reduction), penyajian data (data display), dan penarikan kesimpulan/ verifikasi data (conclusion drawing/ verification).

\section{HASIL PENELITIAN DAN PEMBAHASAN}

Sekolah Menengah Kejuruan Negeri 1 Solok Selatan merupakan sekolah menengah kejuruan tertua di Kabupaten Solok Selatan dan Kabupaten Solok (sebelum Kabupaten Solok Selatan mekar dari Kabupaten Solok). Pada awalnya, sekolah ini bernama SMEA PGRI, sekolah swasta, kemudian dinegerikan tahun 1986 dengan nama SMEA Muaralabuh. Setelah itu diganti menjadi SMK Muaralabuh, kemudian diganti lagi menjadi SMK 1 Sungai Pagu dan sekarang bernama SMK Negeri 1 Solok Selatan. Sekolah ini tergolong SMK kelompok Bisnis Manajemen dengan Jurusan Akuntansi, Perkantoran dan Penjualan. Seiring dengan perkembangan daerah, pada tahun 2004 sekolah ini mengembangkan 
diri dengan penambahan dua Jurusan yaitu : TI dan Tata Boga. Pada tahun pada tahun 2010 dikembangkan lagi dengan menambah dua jurusan lagi yaitu Teknik Komputer Jaringan dan Akomodasi Perhotelan.Jadi, di sekolah ini ada 2 (dua) kelompok SMK, yaitu Administrasi perkantoran dan Teknologi rekayasa.SMK Negeri 1 Solok Selatan merupakan sekolah kejuruan yang memiliki peserta didik yang cukup banyak jika dibanding dengan sekolah kejuruan lain di Kabupaten Solok Selatan.Jumlah peserta didik SMK Negeri 1 Solok Selatan pada tahun pelajaran 2018/2019 sebanyak 771 orang.

SMK Negeri 5 Solok Selatan resmi menerima peserta didik baru pada tahun pelajaran 2008/2009 tepatnya pada tanggal 14 Juli 2008. Pada awalnya, SMK Negeri 5 Solok Selatan memiliki 3 (tiga) jurusan, yaitu: Teknik Instalasi Tenaga Listrik (TITL), Teknik Elektro dan Teknik Geologi Pertambangan. Pada tahun pelajaran 2009/2010, jurusan Teknik Geologi Pertambangan dihapus, karena guru jurusan geologi tidak ada sama sekali. Sementara itu, jurusan Teknik Elektro diganti menjadi Teknik Elektronika Industri.SMK Negeri 5 Solok Selatan memiliki tiga jurusan, yaitu Teknik Instalasi Tenaga Listrik, Teknik Elektronika Industri dan Teknik Komputer Jaringan.Jumlah peserta didik pada tahun pelajaran 2018/2019 adalah 416 orang.

Penguatan pendidikan karakter bernuansa surau dan budaya Minangkabau dalam program intrakurikuler di SMK Negeri 1 Solok Selatan dilakukan secara intensif sejak tahun pelajaran 2013/2014.Sedangkan SMK Negeri 5 Solok Selatan dimulai pada tahun pelajaran 2014/2015.Sebelum tahun pelajaran 2013/2014, penguatan pendidikan karakter dalam program intrakurikuler belum maksimal. Selmi, Pengawas SMK untuk wilayah Kabupaten Solok Selatan menjelaskan bahwa penguatan pendidikan karakter ke dalam program intrakurikuler sekolah berpedoman kepada Pergub Sumatera Barat Nomor 73 Tahun 2012 tentang Petunjuk Pelaksanaan Pendidikan Karakter pada Sekolah/Madrasah di Sumatera Barat dan Pedoman Pengintegrasian Pendidikan Al Qur'an dan Budaya Alam Minangkabau pada setiap mata pelajaran di SMA dan SMK.Penguatan karakter peserta didik bernuansa surau dan budaya Minangkabau penting diterapkan di SMK dengan tujuan agar peserta didik SMK memiliki mental dan karakter Islam/surau dan berbudaya Minangkabau. Raymond, Kasi Kurikulum dan Kesiswaan SMK menjelaskan bahwa pelaksanaan penguatan karakter di SMK berpedoman kepada Pergub Sumatera Barat Nomor 73 Tahun 2012.Pelaksanaan kegiatan harus dilaporkan kepada Bidang Pembinaan SMK Dinas Pendidikan Provinsi Sumatera Barat setiap akhir semester berjalan.Penguatan pendidikan karakter bernuansa surau dan budaya Minangkabau dalam program intrakurikuler di SMKN 1 dan SMKN 5 Solok Selatan pada intinya adalah sebuah proses mengintegrasikan (menyatukan) nilai-nilai karakter ke dalam pembelajaran. Dengan kata lain, penguatan karakter ke dalam intrakurikuler adalah guru mengintegrasikan nilai-nilai karakter surau dan budaya Minangkabau ke dalam proses pembelajaran, baik di kelas maupun di luar kelas. 
Hasil wawancara peneliti dengan Wakakur SMKN 1 Solok Selatan, diperoleh keterangan tentang teknik penilaian yang digunakan oleh majelis guru dalam mengevaluasi pelaksanaan penguatan pendidikan karakter, yaitu jurnal peserta didik, visit home (melihat peserta didik langsung ke rumah), penilaian sikap, dan lain-lain. Teknik penilaian ini tercantum dalam dokumen silabus dan RPP guru yang bersangkutan.Muhnadi, guru PAI di SMKN 1 Solok Selatan memaparkan bahwa perubahan karakter siswa dinilai secara formal, yaitu menuliskan huruf $A$, B, C, atau D dalam format nilai sikap siswa.Nilai ini diserahkan kepada wali kelas untuk direkap dan ditulis dalam rapor (bukti daftar nilai terlampir). Sedangkan Teti Nazraini, guru Matematika di SMKN 5 Solok Selatan juga menilai sikap peserta didik dalam pembelajaran dengan membuat daftar nilai sikap berupa jurnal siswa. Bukti ini dipergunakan oleh wali kelas dan guru BK.Hasil wawancara peneliti di SMKN 1 Solok Selatan, diketahui bahwa ada beberapa kiat yang digunakan oleh guru mapel dalam menanamkan nilai-nilai karakter Surau dan budaya Minangkabau dalam kegiatan belajar di kelas, yaitu : (a) Guru melakukan kegiatan tilawah Al Qur'an sebelum memulai pembelajaran. Tilawah Al Qur'an dilakukan oleh 5 (lima) atau 6 (enam) peserta didik secara bergantian. Ayat yang dibaca ditentukan oleh guru sesuai dengan materi apa yang akan disajikan; (b) Guru membiasakan peserta didik mengucapkan salam sebelum dan sesudah pembelajaran; (c) Khusus untuk peserta didik yang mendapat nilai diatas KKM, guru memberi tugas pengayaan berupa mencari dan menjelaskan tokoh/ilmuan
Islam yang sesuai dengan materi pelajaran. Contohnya: materi PAI kelas XII (dua belas) Bab VI Sejarah Perkembangan Islam di Indonesia, maka guru menugaskan siswa untuk mencari tokoh penyebar Islam di Kabupaten Solok Selatan, yaitu Syech Maulana Syofie (ulama besar Sungai Pagu Solok Selatan, hidup antara tahun 1730 - $1818 \mathrm{M}$ ); dan (d) Guru menyuruh peserta didik membuat pepatah Minangkabau dalam buku catatan sesuai materi yang telah ia pelajari. Contohnya materi PKn SMK Kelas X Semester 1.

Sedangkan guru mapel di SMKN 5 Solok Selatan menggunakan beberapa cara dalam menanamkan dan membiasakan nilai-nilai karakter Al Qur'an dan budaya Minangkabau, yaitu (a) Tilawah Al Qur'an sesuai dengan materi yang akan disajikan. Guru menugaskan 2 (dua) orang peserta didik untuk membaca ayat Al Qur'an dan terjemah ayat. Lalu guru memberitahu kepada peserta didik bahwa ayat tersebut berkaitan dengan materi pelajaran; (b) Memberi contoh teladan kepada peserta didik. Seperti guru tidak terlambat datang ke sekolah, tidak merokok di sekolah, dan berpakaian rapi; dan (c)Guru memberi tugas kepada peserta didik tentang gambaran jorong/nagari dimana peserta didik tersebut menetap (seperti mapel Sejarah). Contohnya pada materi Sejarah SMK Kelas X Semester 1 tentang Bab I Menelusuri Peradaban Awal di Kepulauan Indonesia.Danil Saputra, peserta didik kelas XI jurusan TITL SMKN 5 Solok Selatan menyebutkan bahwa belum semua guru mapel yang mengajar di kelasnya menerapkan pembelajaran terintegrasi pendidikan karakter bernuansa surau dan budaya Minangkabau. Ia menyebutkan beberapa 
guru mapel yang telah mengajar dengan terintegrasi pendidikan karakter, antara lain mapel PAI-BP, PKn, IPS, IPA, Bahasa Indonesia, Seni Budaya, Prakarya, Fisika, dan Bimbingan Konseling. Sedangkan guru mapel produktif/kejuruan belum melaksanakan.Berdasarkan uraian di atas, maka dapat disimpulkan bahwa guruguru di SMKN 1 dan 5 Solok Selatan telah melakukan proses integrasi nilai-nilai karakter bernuansa surau dan budaya Minangkabau ke dalam proses belajar mengajar (intrakurikuler) melalui tiga tahapan, yaitu perencanaan (berupa menyusun silabus dan RPP), pelaksanaan (di kelas), dan penilaian (sesuai Kurikulum 2013). Selain itu, guru memberi contoh langsung penerapan nilai-nilai karakter surau dan budaya Minangkabau di sekolah.

Peraturan Gubernur Sumatera Barat Nomor 73 Tahun 2012 tentang Petunjuk Pelaksanaan Pendidikan Karakter pada Sekolah/Madrasah di Sumatera Barat menegaskan bahwa kegiatan ekstrakurikuler di sekolah/madrasah termasuk SMK terdiri atas 3 (tiga) bentuk, yaitu (a) kegiatan ekstrakurikuler keagamaan/Islami/surau; (b) kegiatan ekstrakurikuler nasional/kebangsaan; dan (c) kegiatan ekstrakurikuler budaya Minangkabau/lokal. Mulzamra, Kepala SMKN 5 Solok Selatan mengatakan bahwa setiap kegiatan ekstrakurikuler di SMKN 5 Solok Selatan memiliki timpembina yang dibentuk dalam rapat dinas awal semester dan diberi SK Kepala Sekolah. Sedangkan di SMKN 1 Solok Selatan, tim Pembina kegiatan ekstrakurikuler dibentuk dalam rapat OSIS yang dikoordinasikan oleh Wakasis dan juga diberi SK oleh Kepala Sekolah. Selanjutnya, Efrizol menjelaskan bahwa setelah SK diberikan, maka masing- masing pembina kegiatan ekstrakurikuler membuat program kerja dan anggaran dana yang dibutuhkan.Dari uraian temuan penelitian diatas, masing-masing SMK yang telah diteliti, yakni SMKN 1 dan SMKN 5 Solok Selatan telah melaksanakan kegiatan ekstrakurikuler sesuai Pergub, namun terdapat perbedaan, baik dari segi kualitas, kuantitas, dan keunggulan kegiatan yang ditonjolkan. Untuk lebih jelasnya, perhatikan tabel di bawah ini:

Tabel 1.

Bentuk-bentuk kegiatan ekstrakurikuler di SMKN 1 Solok Selatan

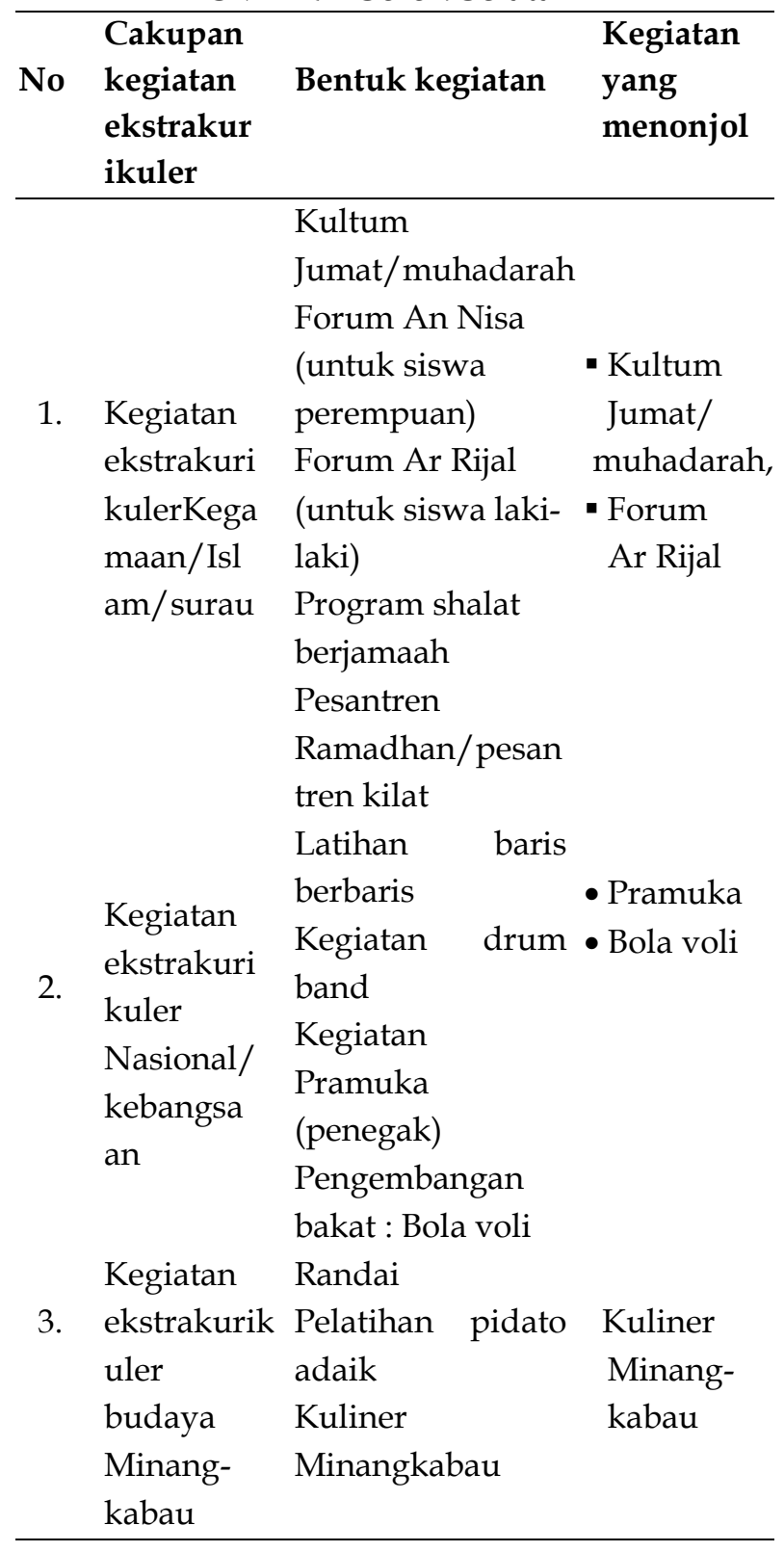


Sedangkan kegiatan ekstrakurikuler yang dilaksanakan di SMKN 5 Solok Selatan adalah:

Tabel 2.

Bentuk-bentuk kegiatan ekstrakurikuler di SMKN 5 Solok Selatan

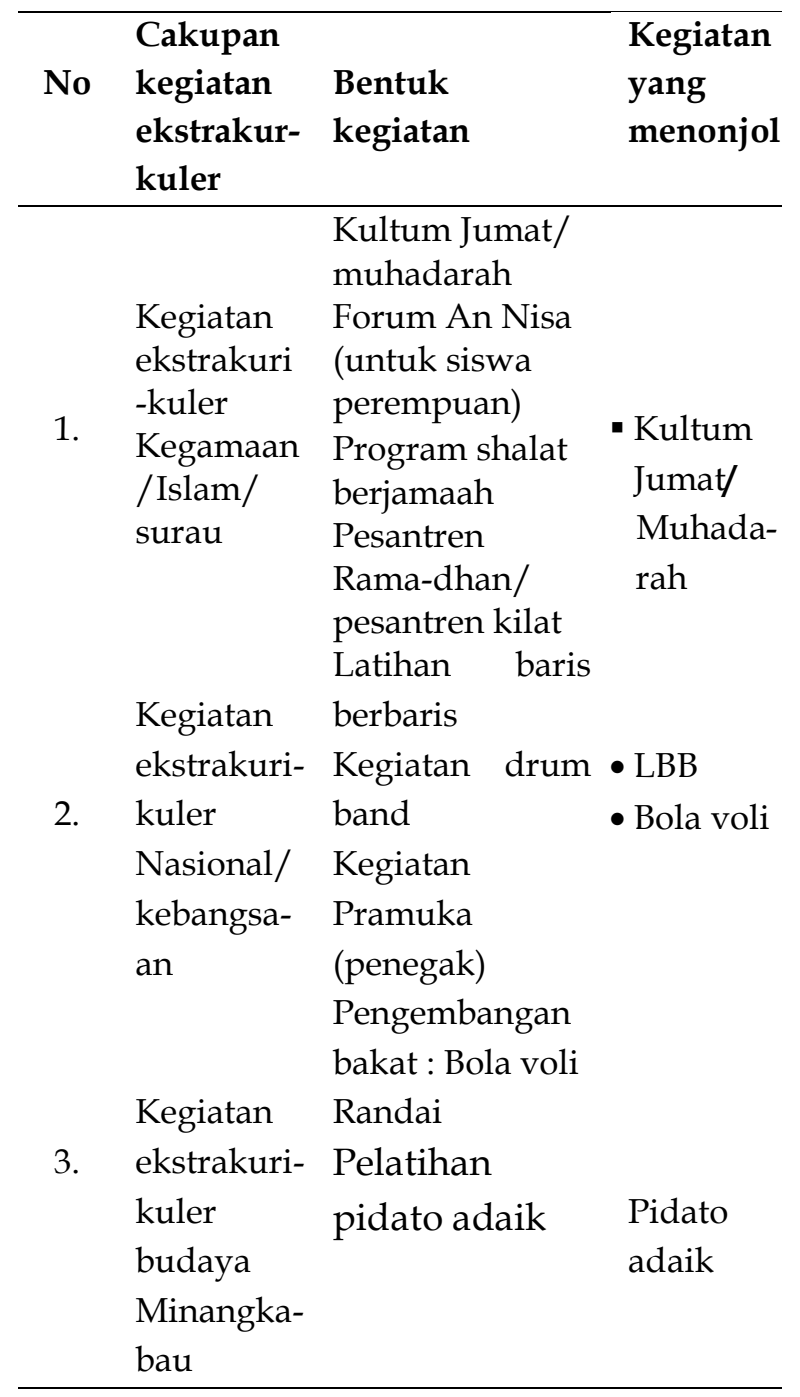

Pengembangan budaya sekolah/ kultur sekolah berperan penting dalam memperkuat pendidikan karakter bernuansa surau dan budaya Minangkabau di SMK Negeri Kabupaten Solok Selatan. Nilai-nilai budaya sekolah yang dikembangkan sejalan dengan nilainilai pendidikan karakter. Hendrimon, Waka Kesiswaan SMKN 1 Solok Selatan menjelaskan bahwa pengembangan budaya/kultur sekolah di SMKN 1 Solok Selatan mengikuti aturan yang tercantum dalam Pergub Sumatera Barat Nomor 73 Tahun 2012 tentang Petunjuk Pelaksanaan Pendidikan Karakter di Sekolah/Madrasah, tepatnya pada Pasal 14. Pengembangan budaya/kultur sekolah di SMKN 1 Solok Selatan dilakukan dengan cara sebagai berikut, yaitu (a) membuat peraturan yang kondusif untuk menerapkan pendidikan karakter; (b) Keterlibatan semua warga sekolah dalam pembelajaran yang berkarakter; (c) keterlibatan semua warga sekolah dalam perawatan, pemanfaatan, pemeliharaan; (d) penanaman budaya bersih dan nyaman; dan (e) Sekolah bebas asap rokok. SMKN 1 Solok Selatan telah menerapkan kawasan sekolah sebagai kawasan bebas asap rokok. Bagi guru lakilaki yang merokok telah disediakan ruang khusus. Sedangkan peserta didik laki-laki yang kedapatan merokok 1 kali di sekolah maka peserta didik tersebut akan dikenakan poin 50 dan apabila mengulangi 1 kali, maka poinnya 100, langsung dikembalikan kepada orang tuanya. Kebijakan ini dilaksanakan berdasarkan Peraturan Bupati (Perbup) Solok Selatan Nomor 19 Tahun 2015 tentan Kawasan Tanpa Rokok (KTR).

$$
\text { Pengembangan budaya/kultur }
$$
sekolah di SMKN 5 Solok Selatan dilakukan melalui beberapa kegiatan, antara lain adalah (a) Penerapan program pendidikan lingkungan; (b) Penerapan tata tertib peserta didik secara adil dan proporsional oleh semua personil sekolah; (c) Sekolah bebas asap rokok, sesuai dengan Peraturan Bupati (Perbup) Solok Selatan Nomor 19 Tahun 2015 tentan Kawasan Tanpa Rokok (KTR); dan (d) Penanaman perilaku 5 S (salam, senyum, sapa, sopan, santun), saling hormat dan kebersamaan.SMKN 5 Solok Selatan juga mengembangkan budaya/kultur sekolah 
sebagai upaya memperkuat pendidikan karakter peserta didik. Budaya/kultur sekolah yang dikembangkan di SMKN 5 Solok Selatan program pendidikan lingkungan (environment education). Walaupun SMKN 5 Solok Selatan belum masuk kategori sekolah adiwiyata, tetapi seluruh stakeholder sekolah telah berkomitmen untuk menjalankan program pendidikan lingkungan sebagai usaha memperkuat karakter peserta didik. Beberapa program sekolah yang termasuk pendidikan lingkungan adalah keterlibatan semua warga sekolah dalam perawatan dan pemeliharaan lingkungan sekolah (taman sekolah, WC sekolah, dan drainase sekolah), penanaman budaya bersih dan nyaman (seperti setiap semester diadakan lomba kelas terbersih dan nyaman), dan sekolah bebas asap rokok.

\section{PENUTUP}

Kesimpulan penelitian ini adalah (1) Penerapan program penguatan pendidikan karakter bernuansa surau dan budaya Minangkabau dalam kegiatan intrakurikuler (proses pembelajaran) di SMKN 1 dan SMKN 5 Solok Selatan merupakan sebuah proses yang dilakukan oleh guru mata pelajaran dalam memasukkan nilai-nilai karakter bernuansa surau dan budaya Minangkabau ke dalam setiap langkah pembelajaran. Nilai-nilai karakter ditanamkan ke dalam perangkat pembelajaran dan dicontohkan langsung oleh guru yang bersangkutan (seperti berdoa dan tilawah Al Qur'an sebelum dan sesudah kegiatan pembelajaran, sehingga terlihat nuansa surau); (2) Penerapan program penguatan pendidikan karakter bernuansa surau dan budaya Minangkabau dalam kegiatan ekstrakurikuler di SMKN 1 dan SMKN 5 Solok Selatan adalah proses mengintegrasikan nilai-nilai karakter surau dan budaya Minangkabau ke dalam berbagai bentuk kegiatan ekstrakurikuler. Kegiatan ekstrakurikuler yang bernuansa surau terlihat dalam kegiatan muhadarah (kultum Jumat), forum An Nisa, forum Ar Rijal (mengaji ilmu-ilmu keIslaman dengan metode halaqah), pesantren, dan shalat berjamaah. Sedangkan penguatan nilai karakter budaya Minangkabau terlihat dalam kegiatan randai, pidato adat, dan kuliner Minangkabau; dan (3) Pengembangan budaya sekolah merupakan cara atau metode penguatan karakter siswa SMK yang tercantum dalam Pergub Sumatera Barat Nomor 73 Tahun 2012. Pengembangan budaya sekolah yang menonjol di SMKN 1 Solok

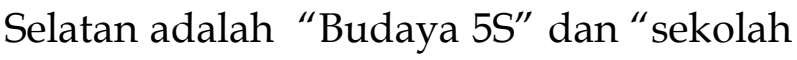
adiwiyata". Sedangkan pengembangan budaya sekolah yang menonjol di SMKN 5 Solok Selatan adalah "Program Sekolah Sehat dan Bebas Asap Rokok".Budaya sekolah ditanamkan oleh seluruh warga sekolah melalui komitmen bersama.

Sedangkan saran-saran antara lain adalah (1) perlu peningkatan pemahaman guru-guru SMK terhadap mekanisme (cara) mengimplementasikan nilai-nilai karakter bernuansa surau dan budaya Minangkabau sehingga peserta didik lebih berkarakter lagi; (2) perlu adanya peningkatan jumlah dan mutu kegiatan ekstrakurikuler bernuansa surau dan budaya Minangkabau di SMKN 1 dan SMKN 5 Solok Selatan, sehingga nilainilai karakter yang muncul akan semakin kuat; dan (3) perlu dilaksanakan komitmen kuat dari semua personil yang ada di sekolah untuk bersama-sama melaksanakan program penguatan 
pendidikan karakter bernuansa surau dan budaya Minangkabau di SMK yang ada di Kabupaten Solok Selatan.

\section{REFERENSI}

Abdullah, M. Yatimin. Studi Akhlak dalam Perspektif Al Qur'an. Jakarta: Amzah. 2007.

Adisusilo, Sutardjo. Pembelajaran Nilai Karakter, Konstruktivisme dan VCT Sebagai Inovasi Pendekatan Pembelajaran Afektif. Jakarta: PT. Remaja Rosdakarya. 2012.

Arikunto, Suharsimi. Prosedur Penelitian, Suatu Pendekatan Praktik. Jakarta: PT. Rineka Cipta, 2006.

Azra, Azyumardi. Surau, Pendidikan Islam Tradisional Dalam Transisi dan Modernisasi. Jakarta: Logos Wacana Ilmu. 2003.

Aziz, Yahya. "Penguatan Mata Kuliah Pendidikan Agama Islam di Perguruan Tinggi Umum".Jurnal Sosial Humaniora. Volume 4 Nomor 2. Surabaya: UIN Sunan Ampel. 2016.

Azmi, Memen Permata. "Mengembangkan Kemampuan Analogis Matematis", Journal Cendikia: Jurnal Pendidikan Matematika, Volume 1. No. 1. Mei 2017. 100-111. ISSN 2579-9258.Fakultas Tarbiyah dan Keguruan.Universitas Islam Negeri Sultan Syarif Kasim Riau. 2017.

Citra, Yulia. "Pelaksanaan Pendidikan Karakter Dalam Pembelajaran". Jurnal Ilmiah Pendidikan Khusus. Volume 1.Nomor 1.Januari 2012. Padang: UNP. 2012.
Demina, "Membumikan Budaya Lokal dalam Membangun Karakter Bangsa". Jurnal Pendidikan Karakter. Batusangkar: IAIN Batusangkar. 2017. Di unduh pada 17-02-2019.

Emzir.Metodologi Penelitian Pendidikan Kuantitatif dan Kualitatif.Jakarta: PT. Raja Grafindo Persada. 2015.

Erliani, Sa'adah. "Peran Gerakan Pramuka untuk Membentuk Karakter Kepedulian Sosial dan Kemandirian (Studi Kasus di SMK Ukhwah Banjarmasin", Jurnal Muallimuna.Volume 2.Nomor 1. Oktober 2016. Banjarmasin: STKIP PGRI Banjarmasin). di unduh pada 17 November 2018.

Furkan, Nuril. Pendidikan Karakter Melalui Budaya Sekolah. Jakarta: Magnum. 2017.

Gunawan.Pendidikan Karakter (Konsep dan Implementasi). Bandung: Alfabeta. 2012.

Hamid, Abdullah. Penanaman Nilai-Nilai Karakter Siswa SMK Salafiyah Prodi TKJ Kajen Margoyoso Pati Jawa Tengah, Jurnal Pendidikan Vokasi.Volume 3.Nomor 2.Juni 2013. Yogyakarta: PPs Universitas Negeri Yogyakarta. 2013.

Hidayati, Nia. Memberi Ketegasan dalam Mendidik Anak.Bandung: CV. Angkasa. 2015.

Hidayat, Nurul. "Metode Keteladanan dalam Pendidikan Islam".Jurnal Pendidikan TA'ALLUM. Vol. 03.No. 02. November 2015. Tulungagung: IAIN Tulungagung. 2015. 
Holliday, Adrian. Doing and Writing Qualitative Reseach. USA: Sage Publications Inc. 2002.

Idi, Abdullah. Sosiologi Pendidikan. Jakarta: Rahagrasindo Perkasa. 2011.

Jaya, Yahya. Wawasan Profesional Konseling Islam.Padang: Hayfa Press. 2015.

Kemendiknas.Pedoman Pelaksanaan Pendidikan Karakter. Jakarta: Balitbang Puskurbuk. 2011.

Kementerian Pendidikan dan Kebudayaan.Kepramukaan: Bahan Ajar Implementasi Kurikulum 2013 Untuk Kepala Sekolah. Jakarta: Kemendikbud. 2014.

Kesuma, Dharma, dkk, Pendidikan Karakter: Kajian Teori dan Praktik di Sekolah. Bandung: Remaja Rosdakarya. 2015.

Koentjaraningrat.Pengantar Ilmu Antropologi. Jakarta: Rineka Cipta. 1990.

Koesoemo, Doni. Pendidikan Karakter: Strategi Mendidik Anak di Zaman Modern. Jakarta: PT. Grasindo, 2007.

Kurniawan, Heru Edi, dkk. "Integrasi Pendidikan Karakter dalam Pengembangan Perangkat Pembelajaran Berbasis Problem Base Learning di SMK".Jurnal Pendidikan. Volume 5.Nomor 1. Surakarta: Universitas Sebelas Maret. 2014.

Kustanti, Niken. "Hubungan antara Ketaatan Peraturan Baris Berbaris dalam Kegiatan Pramuka dan Disiplin Siswa". Jurnal Pendidikan. Edisi 22 Tahun ke-5. 2016. Yogyakarta: UNY. 2016.
Lazuardi. “Ekspresi Masyarakat Minangkabau dalam Mencari Kata Mufakat: Studi Kasus". Jurnal Ilmu Pengetahuan dan Karya Seni.Volume 14.Nomor 1.Juni 2012. ISSN:1412-1662.

Padangpanjang: ISI. 2012.

Majid, Abdul dan Dian Andayani.Pendidikan Karakter Perspektif Islam.Bandung: PT. Remaja Rosdakarya. 2013.

Marzuki.Pendidikan Karakter Islam. Jakarta: Amzah. 2015.

Manaf, Maimunah. Sistem Pendidikan Surau: Karakteristik, Isi, dan Literatur Keagamaan. Journal of Islamic Education UIN Raden Fatah Palembang.Volume 17 Nomor 02. Tahun 2012.

Manan, Imran.Pengantar Antropologi Pendidikan. Jakarta: Depdikbud Dirjen Dikti. 1989. - Dasar-Dasar Sosial Budaya Pendidikan. Jakarta: Depdikbud Dirjen Dikti. 1989.

Ma'rifataini, Lisa'diyah. "Pengaruh Kegiatan Intrakurikuler dan Ekstrakurikuler terhadap Pembentukan Karakter Siswa di SMAN $09 \quad$ Bandar Lampung".Jurnal Penelitian Pendidikan Agama dan Keagamaan.Volume 14.Nomor 02. Jakarta: Puslitbang Kemenag RI. 2016.

Megawangi, Ratna. Pendidikan Karakter: Solusi Tepat untuk Membangun Bangsa. Bogor: Indonesia Heritage Foundation. 2004. 
Mulyasa, E. Manajemen Pendidikan Karakter. Jakarta: Bumi Aksara. 2014.

Muslich, Masnur. Pendidikan Karakter: Menjawab Tantangan Krisis Multidimensional. Jakarta: Bumi Aksara. 2011.

Musanna. "Revitalisasi Kurikulum Muatan Lokal Untuk Pendidikan Karakter Melalui Evaluasi Responsif". Jurnal Pendidikan dan Kebudayaan.Volume 16. Edisi Khusus III. Oktober 2010. Aceh Tengah: Sekolah Tinggi Islam Gajah Putih Takengon. 2010.

Noer, Ali, dkk."Upaya Ekstrakurikuler Kerohanian Islam (ROHIS) dalam Meningkatkan Sikap Keberagamaan Siswa di SMK Ibnu Taimiyah Pekanbaru".Jurnal Al Thariqah.Volume 2.Nomor 1.Tahun 2017.ISSN 2527-9610. Pekanbaru: Universitas Islam Riau. 2017.

Nizar, Samsul. Sejarah Sosial dan Dinamika Intelektual Pendidikan Islam di Nusantara.Jakarta: Kencana. 2014.

Rachman, Budhy Munawar (Ed.). Pendidikan Karakter: Pendidikan Menghidupkan Nilai untuk Pesantren, Madrasah dan Sekolah. Jakarta: The Asia Foundation. 2017.

Ramayulis.Ilmu Pendidikan Islam.Jakarta: Kalam Mulia. 2015. . Ilmu Pendidikan Islam. Jakarta: Kalam Mulia. 2006. . Psikologi Agama. Jakarta: Kalam Mulia. 2013.
Rosa, Femillia, dkk. "Penerapan Pendidikan Karakter Peduli Lingkungan Melalui Metode Inkuiri Terhadap Sikap dan Perilaku Siswa SMKN 6 Banda Aceh".Jurnal Biotik.ISSN: 23379812. Volume 2.Nomor 1.Edisi April 2014. Banda Aceh: Universitas Syiah Kuala. 2014.

Rubei, Muhammad Anwar. “Integrasi Pendidikan Karakter Dalam Pembelajaran IPA SMK Untuk Mengembangkan Kemandirian Siswa di SMKN Kota Pontianak". Jurnal Pendidikan Sosial.Volume 2 Tahun 2. Pontianak: IKIP PGRI. 2015.

Rusman.Belajar dan Pembelajaran Berorientasi Standar Proses Pendidikan. Jakarta: Kencana, 2017.

Rukmana, Reza, dkk. “Membumikan Nilai Budaya Lokal Minangkabau Dalam Membangun Karakter Bangsa". Jurnal Pengembangan Budaya-FBS.Volume 2.Nomor 2.Desember 2014. Bandung: Universitas Pajajaran. 2014.

Samad, Duski. "Strategi Penanaman dan Pengamalan Nilai Pendidikan Rohani Bernuansa Surau di Sekolah".

https://profduski.wordpress.com/2016 106/12/strategi-penanaman-danpengamalan-nilai-pendidikan-rohanibernuansa-surau-di-sekolah. $\quad$ di unduh pada 17-02-2019. 
Saidah, Nur. "Pendidikan Agama Islam, Problem dan Tantangannya sebagai Komponen Matakuliah Pengembangan Kepribadian". Jurnal Pendidikan Agama Islam.Volume IV.Nomor 1. Pekanbaru: UIN Susqo. 2007.

Samani, Muchlas dan Hariyanto.Konsep dan Model Pendidikan Karakter.Bandung: PT. Remaja Rosdakarya. 2016.

Samudro, Rio, dkk. "Nilai-Nilai Budaya Minangkabau Dalam Teks Pidato Batagak Gala Panghulu Karya H.Idrus Hakimy Datuak Rajo Panghulu", Jurnal Pendidikan Bahasa dan Sastra Indonesia. Volume 1 Nomor 1. September 2012. Padang: UNP. 2012.

Silberman, Melvin.L. Active Learning: 101 Cara Belajar Siswa Aktif, terjemahan Raisul Muttaqien. Bandung: Nusamedia dan Nuansa. 2004.

Sugiyono.Metode Penelitian Kombinasi, Mixed Method. Bandung: Alfabeta, 2011.

- Metode Penelitian Pendidikan

Pendekatan Kuantitatif, Kualitatif dan RED. Bandung: Alfabeta. 2015.

Suryabrata, Sumadi. Metodologi Penelitian. Jakarta: Rajawali Press. 2013.

Sumahamijaya, Suparman. Pendidikan Karakter Mandiri dan Kewiraswastaan.Bandung: Angkasa. 2003.
Syarif, Miftah, dkk. "Pelaksanaan Pendidikan Karakter dalam Pembelajaran PAI di SMK Hasanah Pekanbaru".Jurnal Al Thariqah. Volume 1.Nomor 1.Juni 2016. Pekanbaru: Universitas Islam Riau. 2016.

Syarbaini, Amirulloh. Pendidikan Karakter Berbasis Keluarga. Jakarta: Ar Ruzz Media. 2016.

Syafri, Ulil Amri. Pendidikan Karakter Berbasis Al Qur'an. Jakarta: PT. Raja Grafindo Persada. 2014.

Tim Penulis IAIN Imam Bonjol Padang.Pedoman Penulisan Karya Ilmiah. Padang: IAIN Imam Bonjol Padang Press. 2014.

Tim Penyusun. Konsep Pembelajaran di SMK.Jakarta: Dirjen Pembinaan SMK. 2012. Peraturan Gubernur Sumatera Barat Nomor 73 Tahun 2012 tentang Petunjuk Pelaksanaan Pendidikan Karakter di Sekolah/Madrasah di Sumatera Barat.

Kamus Besar Bahasa Indonesia.Jakarta: Balai Pustaka. 1989.

Undang-Undang RI Nomor 20 Tahun 2003 tentang Sistem Pendidikan Nasional.Jakarta: Sinar Grafika. 2016.

Undang-Undang Sistem Pendidikan Nasional. Jakarta: Sinar Grafika. 2016.

Peraturan Presiden RI Nomor 87 Tahun 2017 tentang Penguatan Pendidikan Karakter (PPK). https://www.guru-id.com/2017/08/ perpres-tentang-penguatanpendidikan.html. 
Trianto.Pengantar Penelitian Pendidikan bagi Pengembangan Profesi Pendidikan dan Tenaga Kependidikan. Jakarta: Kencana. 2010.

Yulianto, Agus. Makna dan Tantangan Perpres Penguatan Pendidikan Karakter Sesuai Peraturan Presiden Nomor 87 Tahun 2017 tentang Penguatan Pendidikan Karakter. 2017.

Yudha, Redi Indra. "Pengaruh Kegiatan Ekstrakurikuler dan Sikap Belajar Siswa terhadap Hasil Belajar di SMKN Kota Jambi".Jurnal Ilmiah Pendidikan,Volume 16 Nomor 03 Tahun 2016. Batanghari: Universitas Batanghari. 2016.
Yuliawan, Dhedhy. "Pembentukan Karakter Siswa dengan Jiwa Sportif Melalui Pendidikan Jasmani Olahraga dan Kesehatan".Jurnal Sportif.Volume 2.Nomor 1. Mei 2016. ISSN: $2477-$ 3379. Kediri: Universitas Nusantara PGRI Kediri. 2016.

Zuchdi, Darmiyati. Humanisasi Pendidikan.Jakarta: PT. Bumi Aksara. 2009.

Zulnuraini. "Pendidikan Karakter: Konsep, Implementasi dan Pengembangannya di Sekolah". Jurnal DIKDAS. Nomor 1.Vol. 1. September 2012. 
66 || Turast: Jurnal Penelitian dan Pengabdian Vol. 6, No. 1, Januari-Juli 2018 
